\title{
PHILOSOPHY OF THE PROFESSION AND PROFESSIONAL KNOWLEDGE IN THE STRUCTURE OF PROFESSIONAL IDENTITY OF HEI TEACHERS IN RIGA AND SMOLENSK
}

\author{
Jelena Jermolajeva ${ }^{1}$, Tatiana Bogdanova ${ }^{2}$ \\ ${ }^{1}$ University College of Economics and Culture, Latvia, jjerm@latnet.lv \\ ${ }^{2}$ Smolensk State University, Russia, tanbogdan@mail.ru
}

\begin{abstract}
Teacher is a key figure in the implementation of reforms in higher education. Pedagogical research of the professional identity (PI) of teacher, her/his priority values, self-evaluation of performances and professional knowledge and the way how she/he conceptualises the profession at an individual level can lead to the most appropriate strategies to manage the educational reforms successfully. This article presents some results of the Latvian-Russian project 'Professional Identity of Contemporary Pedagogue' implemented in 2014-2016 by researchers of Riga (Latvia) and Smolensk (Russia). In the realisation of project, a hypothetical model of the content of Higher Education Institution (HEI) teacher's PI was created, and HEI teachers' survey was carried out. In total, 198 teachers were surveyed in Riga and Smolensk. The aim of this article is to examine the relevance of the proposed model and analyse the indicators of the first two components of the model: Philosophy of the Profession and Professional Knowledge. The results show that, on the whole, the answers of the Russian and Latvian teachers in the questionnaire are fairly well agreed; however, some differences and peculiarities in the data of Riga and Smolensk were observed. The relevance of the proposed model has been confirmed, and some problems of PI of HEI teachers have been identified. To improve the educational process, executives of the reform and teachers should pay due attention to these problems.
\end{abstract}

Keywords: professional identity (PI); teacher of Higher Education Institution (HEI); philosophy of the profession; professional knowledge.

JEL Classification:I23

\section{Introduction}

The reform of education in Latvia and Russia started long ago, so all the participants of this process, theorists and practitioners, executives of the reform as well as pedagogues feel the need to sum up some of its results. Teacher is a key figure in the implementation of reforms in higher education. Pedagogical research of the professional identity (PI) of teacher, her/his priority values, self-evaluation of performances and professional knowledge and the way how she/he conceptualises the profession at an individual level can lead to the most appropriate strategies to manage the educational reforms successfully (Radulescu 2013).

The study of the teachers' PI was the theme of the Latvian-Russian project 'Professional Identity of Contemporary Pedagogue' implemented in 2014-2016 by researchers of the Riga Teacher Training and Educational Management Academy (Latvia) and the Smolensk State University (Russia), including the authors of this paper. One of the two main directions of the project was PI of Higher Education Institution (HEI) teachers. In the realisation of project, hypothetical model of the content of HEI teacher's PI was created. The model includes six major structural components of the contents of PI: Philosophy of the Profession, Professional Knowledge, Professional Roles, Professional Attitude to Work, Cooperation with Colleagues and Professional Engagement Behaviours (Шпона et al. 2015). According to the model, the questionnaire 'HEI teachers' professional identity' was elaborated and HEI teachers' survey was carried out; 118 teachers of Riga and 80 representatives of Smolensk participated in the anonymous testing. The article presents some results of this empirical study. The aim of the article is to examine the relevance of proposed model of contents of HEI teachers' PI and 
analyse the indicators of the first two components of the model (Philosophy of the Profession and Professional Knowledge) in the samples of Riga and Smolensk.

The results show that, on the whole, the answers of the Russian and Latvian teachers in the questionnaire are fairly well agreed, despite the fact that in the past 25 years, the two public educational systems have been developed independently. However, some differences and peculiarities in the data of Riga and Smolensk were observed. In the process of the research, the relevance of the proposed model of the content of HEI teachers' PI has been confirmed, and some problems of the PI of the contemporary HEI teacher have been identified. To improve the educational process, executives of the reform and teachers should pay due attention to them.

\section{Literature Review}

In overviews as well as in analytical papers, the assertion that subjective factors play an important role in reforming the educational process occurs more and more often. One of these factors is personality of school or higher school teacher (European Commission 2015, Вербицкий 2014, Olsen, Buchanan 2017). The PI of teacher is a complex dynamic unity developing in the interaction of personal and public perceptions of what it means to be a teacher, subjective and social expectations from this profession (Goodson, Cole 1994). Schneider defines identity as 'an active process that reflects individual's ideas about himself and his own development. This process is accompanied by a the sense of his own continuity, coherence, qualitative certainty that enables individual to perceive his life as an experience of the continuous unity of consciousness, the integrity of life goals and everyday behaviors, actions and their meanings, which makes it possible to act consistently' (Шнейдер 2001, 16).

Research of HEI teachers' PI requires structuring the content of this phenomenon. To create the hypothetical model of the content of HEI teacher's PI, the corresponding scientific literature was analysed and generalised. The model was based on the works by Emerson (2010), Beijaard et al. (2004), Healey and Hays (2011) and Woo (2013). For the empirical research, the questionnaire 'HEI teachers' professional identity' was developed using the Professional Identity Scale in Counselling by Woo for the profession of psychologist-counsellor (Woo 2013). Woo's technique was modified to investigate the contents of HEI teachers' PI.

\section{Methodology}

The survey of university teachers carried out using the questionnaire 'HEI teachers' professional identity' was elaborated by Shpona, Vidnere and Jermolajeva (Сенченков, Шпона 2016, 191). The questionnaire contains six blocks, according to the major components of the model: Philosophy of the Profession, Professional Knowledge, Professional Roles, Professional Attitude to Work, Cooperation with Colleagues and Professional Engagement Behaviours. Every block consists of 10 statements; each of them can be evaluated by the appropriate rating from the strong disagreement ( 1 point) to the complete agreement ( 6 points). In total, there are 60 items.

About 118 teachers of Riga Teacher Training and Education Management Academy, Latvian Academy of Sport Education, Latvian Academy of Music and Riga Technical University participated in Riga; 80 representatives of Smolensk State University, Smolensk State Medical University, Smolensk State Agricultural Academy and Smolensk Academy of Physical Culture, Sports and Tourism were surveyed in Smolensk. On the whole, 198 lecturers of Latvian and Russian universities participated in the research.

By Cronbach's alpha method, the indicator of reliability of the questionnaire is 0.84 , which implies that the questionnaire can be recognised as reliable. The distribution of the participants from Riga and Smolensk samples by gender, age, work experience and the presence/absence of scientific degree are shown in Table 1. 
Table 1. Characteristics of Riga and Smolensk samples

\begin{tabular}{|c|c|c|c|c|c|c|c|c|c|c|}
\hline & \multirow[b]{2}{*}{ F/M (\%) } & \multicolumn{4}{|l|}{ Age } & \multicolumn{4}{|c|}{ Work experience } & Sc. degree \\
\hline & & Mean & $\begin{array}{l}\text { Up to } \\
35(\%)\end{array}$ & $\begin{array}{l}36- \\
55 \\
(\%)\end{array}$ & $\begin{array}{l}56 \\
\text { and } \\
\text { above } \\
(\%)\end{array}$ & Mean & $\begin{array}{l}\text { Up to } \\
5(\%)\end{array}$ & $\begin{array}{l}6-15 \\
(\%)\end{array}$ & $\begin{array}{l}16 \\
\text { and } \\
\text { above } \\
(\%)\end{array}$ & $\begin{array}{l}\text { Dr. or } \\
\text { candidate } \\
\text { / Mg. (\%) }\end{array}$ \\
\hline Riga & $76.3 / 23.7$ & 52.8 & 8.5 & 49.2 & 42.4 & 20.0 & 7.6 & 28.0 & 64.4 & $57.6 / 42.4$ \\
\hline Smolensk & $76.4 / 23.6$ & 42.3 & 26.3 & 57.5 & 16.3 & 14.8 & 20.0 & 47.5 & 32.5 & $80.0 / 20.0$ \\
\hline
\end{tabular}

In all the components of PI mean rates, dispersion, standard deviation, statistical mode and coefficient of variation $(\mathrm{CoV})$ were calculated for both samples of respondents ( $\mathrm{CoV}$ up to $33 \%$ is considered to be reliable and accurate to draw conclusions) (Елисеева 2012, 70). Using the coefficient of MannWhitney, statistically significant differences were identified. Within each block of statements and between the blocks, Spearman's rank correlation coefficients were defined by means of Statistica software. The cases of significant correlation have been analysed.

\section{Results}

The general data obtained for the components 'Philosophy of the Profession' and 'Professional Knowledge' are presented in Table 2. The numbers are separated by a slash: the first one is an indicator for Riga; the second one in italics refers to the Smolensk teachers.

Table 2. General statistical indicators for the PI components 'Philosophy of the Profession' and 'Professional Knowledge' (Riga /Smolensk)

\begin{tabular}{|l|l|l|l|l|l|}
\hline Structural components & $\begin{array}{l}\text { Mean } \\
\text { value }\end{array}$ & Dispersion & $\begin{array}{l}\text { Standard } \\
\text { deviation }\end{array}$ & $\begin{array}{l}\text { Coefficient of } \\
\text { variation (\%) }\end{array}$ & Mode \\
\hline 1. Philosophy of the Profession & $5.19 / 5.12$ & $0.97 / 0.99$ & $0.99 / 1.00$ & $19.02 / 19.46$ & $6 / 6$ \\
\hline 2. Professional Knowledge & $4.82 / 4.71$ & $1.15 / 1.49$ & $1.07 / 1.22$ & $22.20 / 25.91$ & $5 / 5$ \\
\hline
\end{tabular}

On the whole, the answers of the Russian and Latvian teachers are fairly well agreed. According to the Mann-Whitney coefficient, the differences between the two samples of respondents are not statistically significant either for the PI taken, as a whole, or for each component separately (Table 3). The similarity of the results confirms the relevance of the proposed model and indicates that it reflects the essential constant characteristics of the studied professional identity. However, there are some peculiarities in the data of the Riga and Smolensk samples.

Table 3. Statistical differences between the variables in Riga and Smolensk samples

\begin{tabular}{|l|l|l|l|l|l|l|l|l|l|l|l|}
\hline \multicolumn{2}{|c|}{ Mann-Whitney U-test for variable PI (Smolensk). The criteria shown are significant for $\mathrm{p}<0.05000$} \\
\hline & $\begin{array}{l}\text { Rank } \\
\text { Sum 1 }\end{array}$ & $\begin{array}{l}\text { Rank } \\
\text { Sum 2 }\end{array}$ & $\mathrm{U}$ & $\mathrm{Z}$ & $\begin{array}{l}\mathrm{p}- \\
\text { level }\end{array}$ & $\mathrm{Z}$ & $\begin{array}{l}\mathrm{p} \text { - } \\
\text { level }\end{array}$ & $\begin{array}{l}\text { Valid } \\
\mathrm{N} 1\end{array}$ & Valid N 2 \\
\hline PI (Riga) & & 0.00 & 0.00 & 1.00 & 0.00 & 1.00 & 0 & 0 \\
\hline $\begin{array}{l}\text { Mann-Whitney U-test for variable 'Philosophy of the Profession' (Smolensk). The criteria shown are } \\
\text { significant for p }<0.05000\end{array}$ \\
\hline
\end{tabular}




\begin{tabular}{|l|l|l|l|l|l|l|l|l|l|l|}
\hline $\begin{array}{l}\text { Philosophy of } \\
\text { the Profession } \\
\text { (Riga) }\end{array}$ & 66.00 & 25.00 & 11.00 & -0.68 & 0.50 & -0.68 & 0.50 & 10 & 3 & 0.57 \\
\hline $\begin{array}{l}\text { Mann-Whitney U-test for variable 'Professional Knowledge' (Smolensk). The criteria shown are significant for } \\
\mathrm{p}<0.05000\end{array}$ \\
\hline $\begin{array}{l}\text { Professional } \\
\begin{array}{l}\text { Knowledge } \\
\text { (Riga) }\end{array}\end{array}$ & $\begin{array}{l}\text { Rank } \\
\text { Sum 1 }\end{array}$ & $\begin{array}{l}\text { Rank } \\
\text { Sum 2 }\end{array}$ & $\mathrm{U}$ & $\mathrm{Z}$ & $\begin{array}{l}\mathrm{p}- \\
\text { level }\end{array}$ & $\mathrm{Z}$ & $\begin{array}{l}\mathrm{p}- \\
\text { level }\end{array}$ & $\begin{array}{l}\text { Valid } \\
\mathrm{N} 1\end{array}$ & $\begin{array}{l}\text { Valid } \\
\mathrm{N} 2\end{array}$ & $\begin{array}{l}2^{*} 1 \\
\text { sided } \\
\text { exact } \mathrm{p}\end{array}$ \\
\hline & 8.50 & 19.50 & 4.50 & 0.19 & 0.85 & 0.19 & 0.85 & 2 & 5 & 0.86 \\
\hline
\end{tabular}

The component 'Philosophy of the Profession' of teachers' PI concerns basic professional values and patterns: the belief in the necessity and importance of the work, the goals of professional work and professional ethics. To study this component of PI, the researchers offered to respondents the following statements for evaluation:

F1. Teacher should promote a holistic physical, mental and social development of student's personality.

F2. One of the teacher's professional values is student's intellectual growth in the learning process.

F3. Curriculum is a means for the development of student's personality.

F4. In the pedagogical process, it is important to recognize the student's personal achievements.

F5. Effective teaching process is based on equitable cooperation between teacher and students.

F6. Research work is an important component of the profession of university teacher.

F7. It is important for me to communicate with young people, help them, and give advice.

F8. If you look at things realistically, the teacher has few opportunities to influence the student (reverse code).

F9. Teacher profession gives opportunities for self-assertion.

F10. I believe that in my profession it is important to follow certain ethical standards.

The data obtained in the survey for each of the statements of this component are presented in Fig. 1 and Table 4.

Table 4. Data for the items of the PI component 'Philosophy of the Profession'

\begin{tabular}{|c|c|c|c|c|c|c|c|c|c|c|c|}
\hline & & F1 & F2 & F3 & F4 & F5 & F6 & F7 & F8 & F9 & F10 \\
\hline \multirow{3}{*}{ 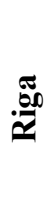 } & Mean rate & 5,37 & 5,43 & 5,15 & 5,48 & 5,40 & 5,36 & 4,97 & 4,45 & 4,50 & 5,74 \\
\hline & Mode & 6 & 6 & 6 & 6 & 6 & 6 & 6 & 5 & 5 & 6 \\
\hline & $\begin{array}{l}\text { Coefficient of } \\
\text { variation (\%) }\end{array}$ & 17,00 & 14,34 & 17,88 & 13,43 & 16,80 & 14,55 & 22,06 & 20,27 & 28,28 & 8,95 \\
\hline \multirow{3}{*}{ 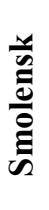 } & Mean rate & 5,29 & 5,46 & 5,18 & 5,45 & 5,24 & 4,95 & 5,01 & 4,14 & 4,80 & 5,70 \\
\hline & Mode & 6 & 6 & 6 & 6 & 6 & 6 & 5 & 5 & 5 & 6 \\
\hline & $\begin{array}{l}\text { Coefficient of } \\
\text { variation (\%) }\end{array}$ & 17,60 & 15,40 & 17,60 & 13,35 & 15,26 & 22,25 & 20,20 & 23,31 & 21,58 & 12,29 \\
\hline
\end{tabular}

The items of the block 'Philosophy of the Profession' received the most consistent and highest rates, compared with items of other components of PI. Teachers believe in the high mission of their profession. The maximum approval is observed in relation to the requirement of strong ethical standards (see item F10 in Fig. 1). The necessity to carry out scientific research is recognised as well. However, there is much less consensus and acceptance regarding possibilities for self-assertion (item 
F9) and real influence on students (F8). Doubts about the latter are more clearly expressed in Smolensk (Fig 1). Probably, this is related to the imbalance and inconsistency in assessing the statement F7 by the teachers of both samples ('It is important for me to communicate with young people, help them, and give advice'). The Smolensk teachers have higher average score, whereas in Riga, mode is higher. It should be noted that in both samples, the teachers' answers to items F7, F8 and F9 are far more inconsistent than their assessments given to other statements of this block, although the data remain within the limits of statistical reliability (in the Smolensk sample, the item F6 belongs also to the group of items with less consistent answers). Thus a discernible contradiction is revealed in PI of a contemporary teacher: recognising her/his mission in the development of student's personality and intellect, she/he is aware that the available tools and technologies are not sufficient to carry out this task. Current communication, advice and help seem to be insufficient for the development of student's personality; the subject-object educational process has been exhausted at this stage of the advancement of higher education. Teacher is aware of the need for a new type of communication and professional interaction, but she/he does not possess necessary tools; the organisation of the educational process cannot provide adequate and effective technologies for the tasks to be solved.

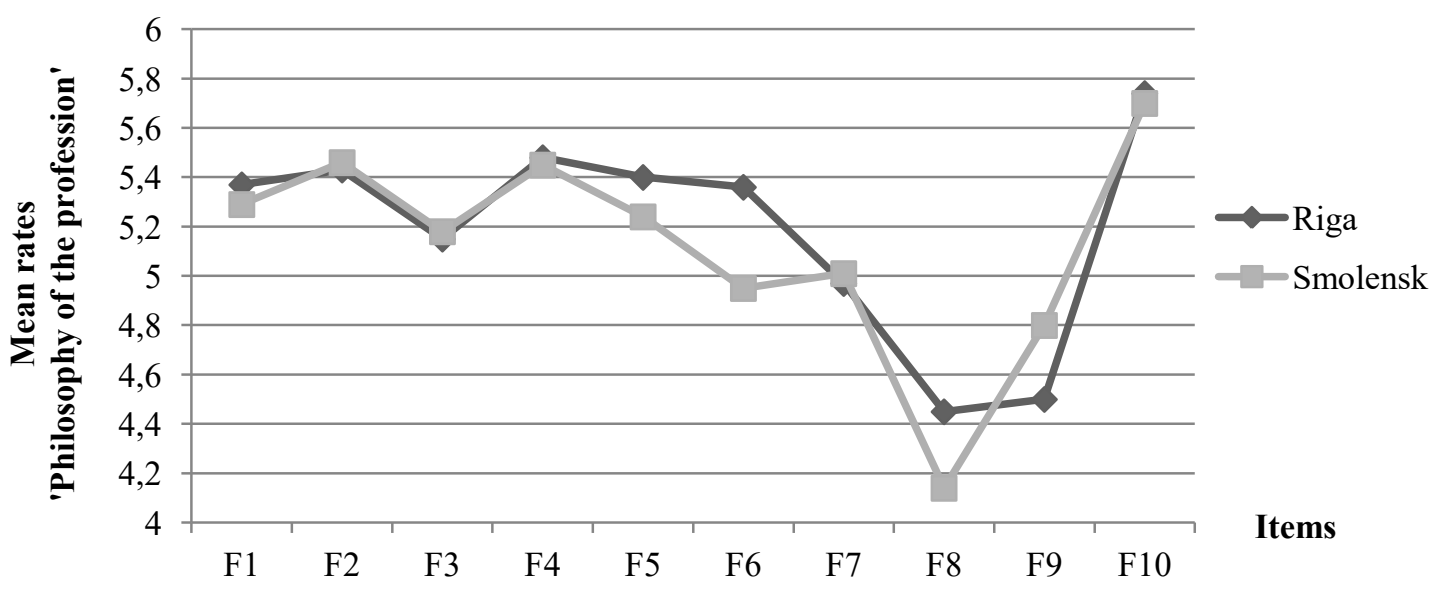

Fig. 1. Mean rates of the statements of the component 'Philosophy of the profession'

Using the Spearman's rank correlation coefficients, the interdependences of statements of the analysed PI component were found (correlations of more than 0.3 are statistically significant, whereas correlations of more than 0.5 and up to 0.7 are moderately strong). Smolensk teachers associate the development of the personality of student mostly with her/his intellectual growth and consider it as their mission (correlation of items F2 and F3 is 0.51). They think that for student's harmonious development, it is necessary to recognise her/his personal achievements. At the same time, they emphasise the complexity of the ethical side of the teacher work: correlation of items F1 and F4 is 0.51 and F4 and F10 is 0.60 . The teachers think that assessing student's achievements in the context of group learning can be ethically conflicting. For Riga teachers, the main means of developing the student's personality is equitable cooperation between her/him and teacher (correlation of F5 and F3 is 0.69), whilst research plays an important role in this cooperation (correlation of F5 and F6 is 0.51). It is in this sense that the mission of the teacher/counsellor/assistant is important (correlation of F6 and F7 is 0.54 ).

The correlation analysis of statements from different blocks of the questionnaire indicates a weak connection between the Philosophy of the Profession and other components of PI in the Smolensk sample (only two moderately strong correlations) and more significant interdependences in Riga (six correlations). In Smolensk, F10 ('I believe that in my profession, it is important to follow certain ethical standards', the highest average score in the block) is the only statement that has the moderately strong correlation of 0.56 with the statement 'I have the necessary diplomas and certificates that give me the right to fulfil my professional role(-s)' (component 'Professional Roles') and 0.54 with 'I feel 
comfortable when working with people' (component 'Professional Attitude to Work'). Thus for the Smolensk teachers, the highly valued teaching mission remains, unfortunately, rather declarative, with little connection with professional activities. Only the ethical aspect of Philosophy of the Profession relates to the professional roles performed by teachers (but only at the level confirmed by diplomas, not at the level of personal attitude) and the system of interpersonal relations.

In Riga sample, Philosophy of the Profession is closely connected with the components Professional Roles, Professional Attitude to Work and Professional Engagement Behaviours (Table 5).

Table 5. Spearman's rank correlations of Philosophy of the Profession with the other PI components (Riga sample)

\begin{tabular}{|c|c|c|}
\hline $\begin{array}{l}\text { Statements from the block } \\
\text { 'Philosophy of the } \\
\text { Profession' }\end{array}$ & Correlating statements in the other PI components & $\begin{array}{l}\text { Correlation } \\
\text { coefficient }\end{array}$ \\
\hline \multirow{3}{*}{$\begin{array}{l}\text { 'Effective teaching process } \\
\text { is based on equitable } \\
\text { cooperation between teacher } \\
\text { and students' }\end{array}$} & $\begin{array}{l}\text { 'I am convinced that my work at the university has a positive } \\
\text { impact on society' (Professional Roles) }\end{array}$ & 0.53 \\
\hline & $\begin{array}{l}\text { 'I realise the need to improve the performance of my } \\
\text { professional role(-s)' (Professional Roles) }\end{array}$ & 0.51 \\
\hline & $\begin{array}{l}\text { 'The teaching profession is unique and valuable for the } \\
\text { development of society' (Professional Engagement } \\
\text { Behaviours) }\end{array}$ & 0.51 \\
\hline \multirow{2}{*}{$\begin{array}{l}\text { 'In the pedagogical process, } \\
\text { it is important to recognise } \\
\text { the student's personal } \\
\text { achievements' }\end{array}$} & $\begin{array}{l}\text { 'I love my profession and would recommend it to young } \\
\text { people' (Professional Attitude to Work) }\end{array}$ & 0.62 \\
\hline & $\begin{array}{l}\text { 'The teaching profession is unique and valuable for the } \\
\text { development of society' (Professional Engagement } \\
\text { Behaviours) }\end{array}$ & 0.53 \\
\hline $\begin{array}{l}\text { 'Teacher profession gives } \\
\text { opportunities for self- } \\
\text { assertion' }\end{array}$ & $\begin{array}{l}\text { 'The teaching profession is unique and valuable for the } \\
\text { development of society' (Professional Engagement } \\
\text { Behaviours) }\end{array}$ & 0.50 \\
\hline
\end{tabular}

From the point of view of the HEI teachers from Riga, pedagogues have a high mission in society, which they implement through cooperation with students, recognition of their achievements and selfrealisation in professional activity. It appears that the Latvian pedagogical community shows higher respect to pedagogy of cooperation than their Russian colleagues.

Professional Knowledge (not only in the subject of study but in pedagogy, psychology, physiology and research as well) and Skills (as the ability to apply this knowledge) are an integral part of PI. For this component, the survey participants were offered the following statements for evaluation:

Z1. I know modern methods of teaching my subject.

Z2. I have the necessary knowledge and skills to develop a study course.

Z3. I have the necessary knowledge and skills for research work.

Z4. I can supervise the student's research work.

Z5. I am familiar with modern systems of evaluation and self-evaluation of student's academic performance.

Z6. I am included in the system of developing the academic and scientific qualifications of teachers.

Z7. I monitor professional literature.

Z8. I know and use foreign languages in my work.

Z9. I am aware of the most important problems of contemporary higher school. 
Z10.I am familiar with the Law on education, state educational standards and regulations.

The data obtained in the survey for each of the statements in this component are presented in Fig. 2 and Table 6.

Table 6. Data for the items of the PI component 'Professional Knowledge'

\begin{tabular}{|c|c|c|c|c|c|c|c|c|c|c|c|}
\hline & & Z1 & $\mathbf{Z 2}$ & $\mathbf{Z 3}$ & $\mathbf{Z 4}$ & $\mathbf{Z 5}$ & Z6 & Z7 & $\mathbf{Z 8}$ & Z9 & Z10 \\
\hline \multirow{3}{*}{ 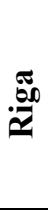 } & Mean rate & 4,85 & 5,06 & 5,02 & 4,99 & 4,48 & 4,50 & 5,28 & 4,69 & 4,63 & 4,72 \\
\hline & Mode & 5 & 5 & 5 & 5 & 5 & 5 & 5 & 5 & 5 & 5 \\
\hline & $\begin{array}{l}\text { Coefficient of } \\
\text { variation (\%) }\end{array}$ & 16,76 & 15,57 & 18,24 & 19,69 & 26,04 & 30,16 & 14,83 & 24,20 & 23,77 & 26,11 \\
\hline \multirow{3}{*}{ 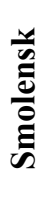 } & Mean rate & 4,88 & 5,21 & 4,95 & 5,13 & 4,68 & 4,59 & 5,11 & 3,40 & 4,46 & 4,66 \\
\hline & Mode & 5 & 5 & 5 & 6 & 5 & 6 & 6 & 6 & 5 & 5 \\
\hline & $\begin{array}{l}\text { Coefficient of } \\
\text { variation }(\%)\end{array}$ & 15,78 & 13,89 & 16,98 & 20,45 & 21,19 & 31,73 & 18,93 & 52,24 & 22,25 & 25,75 \\
\hline
\end{tabular}

In general, the situation for this component of the PI is not bad. The HEI teachers of both samples are included in the system of professional development, and they are aware of the regulatory documents governing education in their countries and monitor professional literature.

The most significant difference in the responses of the two samples was observed in the use of foreign languages (item Z8 in Fig. 2). Though the mode in Smolensk is the maximum (6), the differences in the responses are significant to an extent that they are brought out of the confidence zone (the $\mathrm{CoV}$ is $52.24 \%$ ). The large dispersion of answers shows a problem for the Russian colleagues: very few teachers speak foreign languages well enough or have experience in using them in their work (or the need to use them). This undeniably limits their opportunities in professional activities.

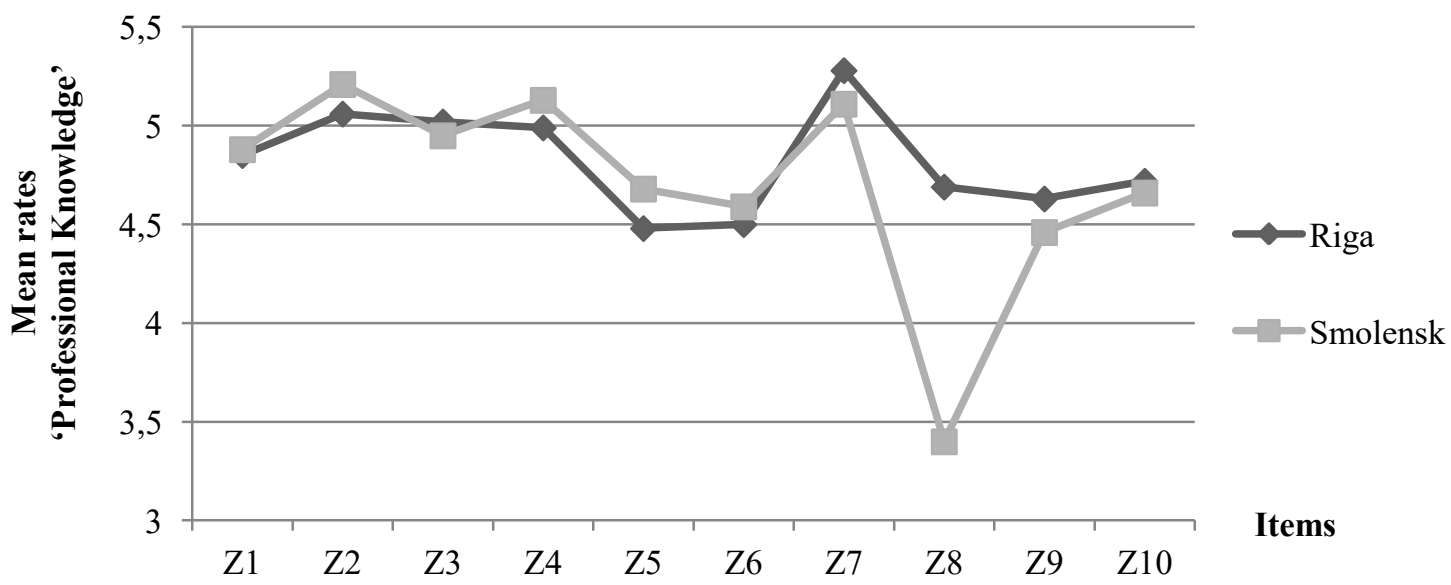

Fig. 2. Mean rates of the statements of the component 'Professional Knowledge'

By the number of rank correlations within the block, the key item for Smolensk teachers is the second statement: 'I have the necessary knowledge and skills to develop a study course'. It has moderately strong correlations with the knowledge of new methods of teaching (item Z1, correlation of 0.55 ) and the skills of the own research and organising research work with students (items Z3 and Z4 with correlations of 0.60 and 0.64 , respectively). It is noteworthy that the correlation connects statements Z1 and Z5 (0.57) and Z5 and Z10 (0.52): for Smolensk teachers, knowledge of the systems of 
evaluation and self-evaluation of student's academic performance indicates the use of modern methods of teaching and meets the requirements of the 'Law on Education of the Russian Federation'. Consequently, for them, the knowledge of new methods of teaching and evaluating of student's academic performance, as well as the skills of research and organising research work, are the priority professional knowledge and skills.

For the Riga sample, the key item of the block (with maximum number of internal correlations) is the ninth statement: 'I am aware of the most important problems of contemporary higher school', which is related to the items Z1 (I know modern methods of teaching my subject', with correlation of 0.50 ), Z8 ('I know and use foreign languages in my work', with correlation of 0.52), and Z10 ('I am familiar with the Law on education, state educational standards and regulations', with correlation of 0.50 ). As for their colleagues in Smolensk, the priority professional knowledge and skills for Riga teachers are in accordance with the Law and normative acts; however, Latvian regulations orient teachers towards foreign experience to a greater extent than in Russia (as knowledge and use of foreign languages by the Riga teachers indicates). The other three correlations, which connect pairs of items Z1 and Z5; Z2 and Z3; and Z3 and Z4 (0.52, 0.54 and 0.77, respectively), correspond to those in Smolensk. Attention is drawn to the strong correlation of Z3 and Z4 in the Riga sample (0.77). According to the teachers' responses, only a lecturer who is engaged in the own research pays much attention to the organisation of research with students. It points to the importance of teacher's research in the pedagogical process and the necessity to increase demands for personal scientific activity of teachers in Riga.

There is only one correlation between the items of the block 'Professional Knowledge' and items from the other components of PI in Riga sample. There is a strong correlation (0.79) between Z8 ('I know and use foreign languages in my work') and the statement 'I can communicate with international colleagues in a foreign language(s)' (the component 'Cooperation with Colleagues'), which seems quite natural.

Except from the above correlation, in the Smolensk sample, there is a moderately strong correlation (0.50) between Z6 ('I am included in the system of developing the academic and scientific qualifications of teachers') and the statement 'I think I am able to make students interested in my subject' (component 'Professional Attitude to Work'). This proves the importance of the system of development of professional qualification for enhancing the teaching skills; teachers are well aware of its benefits.

\section{Conclusions}

The hypothetical model of the content of HEI teacher's PI was confirmed:

- According to the Mann-Whitney coefficient, the differences between the two samples of respondents are not statistically significant; this confirms the relevance of the proposed model of teachers' PI.

- Using the Spearman rank correlation analysis, numerous correlations between the Philosophy of the Profession and other proposed components of the teacher's PI (Professional Knowledge, Professional Attitude to Work and Cooperation with Colleagues) have been revealed. This indicates the validity of the chosen method of the research of teachers' PI.

In the process of the research, some problems of the contemporary teacher's PI have been identified:

- Recognising mission of lecturer in the development of student's personality and intellect, the university teachers are aware that the available tools and technologies are not sufficient to carry out this task effectively.

- Latvian teachers consider the pedagogy of cooperation as an important tool for the development of student's personality; here the joint research work plays an essential role. However, according to the data received, only teachers who are actively engaged in the own scientific activities are able to use this technology effectively.

- Recognising the system of adequate evaluation and self-evaluation of student's academic 
performance as an important tool for the development of student's personality, Russian teachers feel the danger of the possible conflict of individual assessing with the ethical norms of social realisation of the pedagogical process.

- For the Riga sample, the basic professional values and patterns formulated in the items F1F10 of the block 'Philosophy of the Profession' (cooperation with students, awareness of the public significance of the profession, etc.) are effective tools in teachers' professional activities. The Smolensk teachers also highly evaluate the teaching mission; unfortunately, their evaluation is rather declarative, having little connection with their work.

- Insufficient knowledge of foreign languages limits the professional growth of teachers from the Smolensk universities.

- The teaching community of Riga is more focused on the use of foreign experience; the system of professional qualification based on the national pedagogical innovations is not considered by respondents as significant contribution to advancing their teaching skills.

\section{References}

Beijaard, D., Meijer, P.C., \& Verloop, N. (2004). Reconsidering research on teachers' professional identity. Teaching and Teacher Education, (20), 107-128.

Emerson, C.H. (2010). Counselor Professional Identity: Construction and Validation of the Counselor Professional Identity Measure. PhD thesis. Greensboro: The University of North Carolina.

European Commission (2015). The Teaching Profession in Europe. Practices, Perceptions, and Policies. Eurydice Report. Luxembourg: Publications Office of the European Union.

Goodson, I.F., \& Cole, A.L. (1994). Exploring the teacher's professional knowledge: Constructing identity and community. Teacher Education Quarterly, (21), 85-105.

Healey, A.C., \& Hays, D.G. (2011). Defining Counseling Professional Identity from a Gendered Perspective: Role Conflict and Development. Professional Issues in Counseling. On-Line Journal. Spring. Sam Houston State University. [Accessed 20.03.2017]. Available from Internet: http://www.shsu.edu/ piic/DefiningCounselingProfessionalIdentityfromaGenderedPerspective.htm

Olsen, B., \& Buchanan, R. (2017). "Everyone Wants You to Do Everything": Investigating the Professional Identity Development of Teacher Educators. Teacher Education Quarterly, Winter 2017, 9-34.

Radulescu, C. (2013) Is Our Professional Identity Reflected in the European Documents on Education? Procedia - Social and Behavioral Studies, 78 (2013), 205 - 209.

Woo, H.R. (2013). Instrument construction and initial validation: professional identity scale in counseling. PhD thesis, University of Iowa. [Accessed 18.02.2017]. Available from Internet: http://ir.uiowa.edu/etd/2663.

Вербицкий, А.А. (2014). Место и роль преподавателя в процессе реформы образования. Вестник Московского государственного гуманитарного университета им. М.А. Шолохова. Серия: Педагогика и психология, (2), 42-51.

Елисеева, И.И. (2012). Статистика: учебник для бакалавров. Москва: Издательство Юрайт.

Сенченков, Н.П., \& Шпона, А. (Ред.). (2016). Профессиональная идентичность педагога:сравнительное международное исследование. Смоленск: Издательство СмолГУ.

Шнейдер, Л.Б. (2001). Профессиональная идентичность. Москва: Издательство Московского открытого социального университета.

Шпона, А., Виднере. М., \& Ермолаева, Е. (2015). Сущность и структура профессиональной идентичности педагога. Известия Смоленского государственного университета, 2015 (1), 375381. 